\title{
Growth and Slaughter Characteristics of Weaning Male Kids of Turkish Native Goat Breeds
}

\author{
Uğur ŞEN ${ }^{1, *} \mathbb{0}$, Emre ŞİRIN ${ }^{2}$, Ayşe Gül FİLIK ${ }^{2}$, Hasan ÖNDER ${ }^{3}\left(\mathbb{D}\right.$, Dariusz PIWCZYŃSKI $^{4}(\mathbb{D}$ \\ and Magdalena KOLENDA ${ }^{4}$
}

1 Department of Agricultural Biotechnology, Faculty of Agriculture, Ondokuz Mayıs University, Samsun 55139, Turkey

2 Department of Agricultural Biotechnology, Faculty of Agriculture, Kırşehir Ahi Evran University, Kirşehir 40100, Turkey; emre.sirin@ahievran.edu.tr (E.Ş.); aysegulcivaner@ahievran.edu.tr (A.G.F.)

3 Department of Animal Science, Faculty of Agriculture, Ondokuz Mayıs University, Samsun 55139, Turkey; honder@omu.edu.tr

4 Department of Animal Biotechnology and Genetic, Faculty of Animal Breeding and Biology, Bydgoszcz University of Science and Technology, 85-796 Bydgoszcz, Poland; darekp@pbs.edu.pl (D.P.); kolenda@pbs.edu.pl (M.K.)

* Correspondence: ugur.sen@omu.edu.tr; Tel.: +90-36-2312-1919 (ext. 1361)

Citation: ŞEN, U.; ŞİRIN, E.; FILİK, A.G.; ÖNDER, H.; PIWCZYŃSKI, D.; KOLENDA, M. Growth and Slaughter Characteristics of Weaning Male Kids of Turkish Native Goat Breeds. Animals 2021, 11, 2788. https://doi.org/10.3390/ani11102788

Academic Editor: Virgínia Alice Cruz Dos Santos

Received: 19 August 2021

Accepted: 21 September 2021

Published: 24 September 2021

Publisher's Note: MDPI stays neutral with regard to jurisdictional claims in published maps and institutional affiliations.

Copyright: (c) 2021 by the authors. Licensee MDPI, Basel, Switzerland. This article is an open access article distributed under the terms and conditions of the Creative Commons Attribution (CC BY) license (https:// creativecommons.org/licenses/by/ $4.0 /)$.
Simple Summary: The carcass characteristics of Turkish native goat breeds are affected by the rearing conditions after weaning. This study aimed to compare the growth, slaughter, and carcass characteristics of male kids from Angora, Hair, Honaml, and Kilis breeds at weaning age to eliminate the impact of rearing conditions. Honamlı kids had higher birth weight, daily weight gain, carcass weights (hot-cold), and yields (hot-cold) than those of other breeds $(p<0.05)$. Therefore, the Honaml breed could be used as a fattening material genotype due to its superior carcass characteristics compared to other Turkish native breeds.

Abstract: There is little knowledge about the carcass potential of Turkish native goat breeds raised under different rearing conditions. It is necessary to compare the carcass characteristics of these breeds to minimize the effect of the rearing conditions. Therefore, this study aims to compare the growth, slaughter, and carcass characteristics of male kids at weaning age to eliminate the impact of rearing conditions. Kids born to Angora $(n=6)$, Hair $(n=6)$, Honaml $(n=6)$, and Kilis $(n=6)$ Turkish native goat breeds, ranging in age from 2-3 years, were slaughtered at 90 days of weaning age and carcass characteristics were determined immediately. There were differences $(p<0.05)$ among breeds in terms of birth weight (BW) and daily weight gain (DWG) from birth to weaning age. Honamlı kids had higher BW and DWG than those of other breeds $(p<0.05)$. Similarly, carcass weights (hot-cold) and yields (hot-cold) of Honamlı kids were higher compared to kids born to other breeds $(p<0.05)$. Additionally, Honamlı and Hair kids had higher longissimus-dorsi (LD), and semitendinosus (ST) muscle weights compared to Kilis and Angora kids. Interestingly, Kilis kids had lower BW and DWG than those of other breeds $(p<0.05)$. There were significant differences $(p<0.05)$ among breeds in terms of non-carcass parts and organ weights. Positive correlations were calculated between cross-sectional area and weight $(\mathrm{r}=0.793 ; p<0.01)$, length and weight $(\mathrm{r}=0.723 ; p<0.01)$, and depth and weight $(\mathrm{r}=0.698 ; p<0.01)$ in LD muscle of all kids. A similar correlation trend was calculated for the ST muscle (cross-sectional area and weight; $\mathrm{r}=0.699 ; p<0.01$, length and weight; $\mathrm{r}=0.751$; $p<0.01$, and depth and weight; $r=0.528 ; p<0.05$ ) in all kids. In conclusion, the present study results showed that Honamlı kids could be used for fattening material due to their good carcass quality compared to other native breeds.

Keywords: indigenous breeds; meat production; non-carcass parts; organ weight; weaning 


\section{Introduction}

Goat breeding is a traditional animal production branch that is generally carried out in underdeveloped and developing countries [1]. All over the world, goats are raised in non-preferred areas such as mountainous, heath, stony, or rocky land areas, which cannot sustain agricultural activities, and are an essential source of livelihood and food for low-income farmers [2]. The studies conducted in developing countries, in which the number of goats is high, revealed that goat farming has a social aspect besides its economic part [2-4].

According to the data of Food and Agriculture Organization (FAO) for 2019 [5], there were approximately one billion goats in the world. The top five countries with the highest number of goats are India (13.6\%), China (12.5\%), Nigeria (7.5\%), Pakistan (5.6\%), and Bangladesh (6.5\%). Turkey ranks first among European countries in terms of goat population, with its goat assets exceeding 11 million heads, representing approximately $47 \%$ of the European continent's goat inventory [5,6]. Additionally, Turkey has a $1.02 \%$ share in terms of goat assets and is among the top 20 countries in the world [5]. Turkey is an essential country in terms of live animal population and animal genetic resource diversity among European countries.

Goats have material and moral importance in the Anatolian culture and played an essential role in the historical process in the spiritual and economic factors in Turkish people's nutrition, clothing, and shelter [7]. Various native goat breeds, which are bred in different geographical regions and are adapted to those conditions, are raised in Turkey [8]. In addition, goat farming is carried out within farming systems, including village herds or transhumance or nomadic herds in mountainous and forest or less-favored areas, which are not suitable for crop production and other livestock species practices $[9,10]$. Turkey has thirteen national and local native goat breeds named Hair, Angora, Norduz, Honaml, Kilis, Damascus, Gürcü, Ispir, Kaçkar, Abaza, Malta, and Akkeçi. While Angora, Hair, Honaml, and Kilis breeds constitute a large proportion of Turkey's goat population (92\%), other local and exotic breeds account for a meager share $[8,10,11]$.

Although Turkey is among the leading countries in the world in terms of goat assets, almost all of the goat population consists of local breeds with low yield potential, but good adaptation to different climatic conditions $[8,10,11]$. Goat farming is primarily carried out according to the extensive breeding system, with little or no additional feeding and general way of life instead of at a commercial scale in Turkey and many developing countries $[9,10]$. Moreover, kids of indigenous breeds, raised in different geographical regions of Turkey, are grown similarly until weaning, but growth differences occur according to breeding practices linked to the area's conditions following weaning $[8,10,11]$. Kids that will not be used for breeding in traditional goat farming are slaughtered at the age of 4-6 months with a live weight of $10-15 \mathrm{~kg}[12,13]$. Today, consumers primarily in the Mediterranean region prefer the meat of young suckling kids (2-3 months of age with 6-11 kg live weight) because the meat is considered more tender, juicy, and tasty $[14,15]$. There is scarcely any information about the actual fattening potential of kids born to native breeds to produce goat meat, which prevents the profitable goat farming of farmers. Thus, it is necessary to put forward evaluation criteria that will minimize the effect of the region's conditions and determine the fattening potential of the native breeds.

Turkey has seven different geographical regions, and goat breeders similarly raise kids until weaning using traditional farming in each region $[8,10,11]$. In addition, consumers in Turkey and Mediterranean countries prefer weaned kid meat more than beef and lamb [14]. For this reason, determining the carcass characteristics of kids from native breeds at weaning may provide information that will shed light on the future growth potential of these breeds without being affected by the environmental and climatic conditions in those regions. Although there were some studies about fattening performances and carcass characteristics of Angora, Hair, Honamll, and Kilis breeds and their crossbreeding [16-23] in intensive farming, there are no comparative studies about the slaughter and carcass characteristics at the weaning age of these breeds in traditional farming. Therefore, this 
study aims to compare the growth, slaughter, and carcass characteristics of weaned kids born from Angora, Hair, Honamlı, and Kilis breeds raised in traditional farming.

\section{Materials and Methods}

All operations of the study were approved by Kirşehir Ahi Evran University, Local Animal Care and Ethics Committee (approval number: 021013-4.1.9). The study was carried out during the breeding season, which covers the mating, gestation, birth, and growth periods of kids until weaning, of goats in Turkey (from September to May). Male kids were obtained from private farms included in the national sheep and goat-breeding project carried out in five different provinces; Ankara (Angora; $n=6$ ), Tokat (Hair; $n=6$ ), Antalya (Honamli; $n=6$ ), and Kilis (Kilis; $n=6$ ). Secondary data consisted of experimental period meteorological data (monthly averages of temperature, rainfall rate, and relative humidity) of study provinces were obtained from the Turkish State Meteorological Service. Monthly averages of the outdoor temperature $\left({ }^{\circ} \mathrm{C}\right)$ rainfall rate $\left(\mathrm{kg} / \mathrm{m}^{2} / \mathrm{month}\right)$, and relative humidity (\%) during the breeding season for the study areas (Ankara, Tokat, Antalya, and Kilis) are presented in Table 1. Male kids of all breeds were selected from does with singletons and during their second birth and were reared according to the traditional system of the regions, i.e., similar feeding and management practices. The does from each breed were vaccinated for all known diseases in their region by the Provincial Directorate of Agriculture. Health control and internal and external parasite treatments of all does were performed before the experimental period. Kids from each breed were born from February to the beginning of March in the same year. Kids were housed in a pen as groups with their mothers until weaning on each private farm. The kids were fed their mothers' milk until weaning, and according to their appetite of $0.1 \mathrm{~kg} /$ day $/ \mathrm{kid}$, meadow grass hay was offered after 15 days of age. For the first 15 days after birth, the does were kept in the house with their kids. During this period, does were fed $1.0 \mathrm{~kg} /$ day/doe of meadow grass hay. Moreover, water and mineral stone blocks were offered ad libitum to both does and kids. After this period, the does were allowed to pasture graze without additional concentrate in extensive areas during the daytime and to suckle their single kid during the nighttime in a barn where they were offered $0.5 \mathrm{~kg} /$ day / doe of meadow grass hay. The grazing areas of each breed were natural grassland dominated by Anndropogon ischoemum, Festuca arundinacea, Medicago sativa, Trifolium pratense, Bromus cappadocicus, Cynodon dactylon, Astragalus sp., Capsella bursa, Hordeum murinum, Amaranthus sp., and Circium sp. species. No kids were taken out of a pen until weaning age.

Table 1. Average outdoor temperature (OT), rainfall rate (RFR), and relative humidity (RH) during the breeding season in the study areas.

\begin{tabular}{ccccc}
\hline Traits & Ankara & Antalya & Kilis & Tokat \\
\hline OT $\left({ }^{\circ} \mathrm{C}\right)$ & $11.77 \pm 1.88$ & $18.87 \pm 2.03$ & $17.18 \pm 2.19$ & $12.79 \pm 1.99$ \\
$\operatorname{RFR}\left(\mathrm{kg} / \mathrm{m}^{2} / \mathrm{month}\right)$ & $43.6 \pm 10.1$ & $68.0 \pm 21.7$ & $70.8 \pm 20.1$ & $44.01 \pm 8.49$ \\
$\mathrm{RH}(\%)$ & $63.10 \pm 4.25$ & $60.67 \pm 3.23$ & $56.12 \pm 5.14$ & $64.28 \pm 3.29$ \\
\hline
\end{tabular}

All kids were weaned at 90 days of age and, after fasting for one day, were weighed and the daily weight gain (DWG) of all kids was calculated from birth to weaning. All kids were transferred for slaughter to the slaughterhouse. Immediately after the slaughter, the head, pelt, four legs, fats (internal fat and kidney fat), and some organs (lung, liver, kidney, heart, spleen, testis, empty small intestine, and empty reticulo-rumen) were removed. At the same time, the weights of the hot carcass, organs, and non-carcass parts were determined. The carcasses of kids were stored at $4{ }^{\circ} \mathrm{C}$ for $24 \mathrm{~h}$, and the cold carcass weight at the end of the storage period was determined. Hot and cold dressed yields (HCY and CCY) of all kids were calculated as (carcass weight/fasting live weight) $\times 100$. In addition, the chilling loss (CL) of all kids was calculated as HCY-CCY. Following weighing, a crosssection from the mid-belly of the longissimus-dorsi (LD) and semitendinosus (ST) muscles from the right side of the carcasses was taken using a drawing paper. The cross-sectional 
area (CSA) of all muscles was determined by a direct grid reading [24], and muscle depth (MD) and length (ML) were determined by a digital caliper.

The statistical analysis was conducted using a completely randomized design for traits. The statistical analyses were performed using the SPSS 17.0 package program (1999, SPSS, Chicago, IL, USA). The optimum sample size was determined by a simple randomize sampling method, and the results showed that six repeats in each group were enough for a trait, which had the maximum variance. The observed power of the test was $92.07 \%$, which shows that the used sample size was adequate for reliable results. To estimate the best fitting model (linear, quadratic, cubic or logarithmic) of the explanatory variable relative to the response variable, curve estimation was used. Linear regression analysis was used to determine the effect of metric measurements on the weight of muscles. Relationships between variable traits were determined with Pearson correlation analysis using a 95\% confidence interval. Duncan's multiple comparison tests tested significant differences between means. Results were computed as the mean \pm standard error, and statistical significance was declared at $p<0.05$.

\section{Results}

The growth and carcass characteristics and relative weight of non-carcass parts and some organs of male kids born to Turkish native goat breeds are shown in Table 2. The birth weight and DWG of Honaml kids were higher $(p<0.05)$ than those of other breeds. Similarly, Honaml kids had higher $(p<0.05)$ hot and cold carcass weights and yield compared to kids from other breeds. However, the chilling loss of Kilis and Angora kids was lower $(p<0.05)$ than that of Hair and Honamlı breeds. The relative weight of LD (except for Angora) and ST muscles in Honaml kids was higher $(p<0.05)$ than those of other breeds. There were no significant differences among breeds regarding kidney fat proportions, but Hair kids' internal fat (except for Honamli) and total fat ratios were lower than those of other breeds' kids $(p<0.05)$. Angora kids had a higher $(p<0.05)$ relative pelt weight, but the relative weights of feet and empty small intestines were lower in Angora kids than in kids from other breeds. Interestingly, the relative weight of the empty reticulo-rumen in Honamlı kids was significantly lower $(p<0.05)$ than that of different breeds. There were no significant differences among breeds in terms of the relative weights of the lung, liver, kidney, and testis, but the relative weights of the heart and spleen (except for Honamli) in Kilis kids were lower $(p<0.05)$ than those of other breeds' kids.

The analysis of Pearson's correlation coefficients for the pooled data for all breeds showed no significant correlations between the carcass characteristics and metric measurements of muscles. However, positive correlations were calculated between the muscle weight and MD $(\mathrm{r}=0.698 ; p<0.01)$, ML $(\mathrm{r}=0.723 ; p<0.01)$, and CSA $(\mathrm{r}=0.793 ; p<0.01)$ for the LD muscle of all kids (Table 3). A similar correlation trend was calculated for the ST muscle, and there were positive correlations between muscle weight and $\mathrm{MD}(\mathrm{r}=0.528$; $p<0.05), \mathrm{ML}(\mathrm{r}=0.751 ; p<0.01)$, and CSA $(\mathrm{r}=0.699 ; p<0.01)$ in all kids (Table 3).

The results of the curve estimation showed that the shape of all explanatory variables was linear with respect to the response variables. Regression graphs of metric measurements of the weight of LD and ST muscles for 24 kids born to Turkish native goat breeds are presented in Figures 1 and 2, respectively. In the regression analysis, significant relationships were observed between the metric measurements and weights of both muscles. In these models, statistically significant coefficients of determination $\left(R^{2}\right)$ for $M D, M L$, and CSA for muscle weight were found as $0.488(p<0.01), 0.523(p<0.01)$, and $0.628(p<0.01)$, respectively, for LD muscles (Figure 1 ). The resulting regression models were as follows: muscle weight $=-13.929+12.779 \times(\mathrm{MD})$, muscle weight $=-62.870+8.216 \times(\mathrm{ML})$, and muscle weight $=64.925+2.730 \times(\mathrm{CSA})$. According to regression analysis, $\mathrm{MD}$ did not affect muscle weight $\left(R^{2}=0.135\right.$ and $\left.p=0.08\right)$, but significant relationships were observed in the regression analysis for ST muscle, and these models were statistically significant with a coefficient of determination $\left(\mathrm{R}^{2}\right)$ for ML and CSA of $0.563(p<0.01)$ and $0.488(p<0.01)$, 
respectively, for muscle weight (Figure 2). The resulting regression models were as follows: muscle weight $=5.179+3.132 \times(\mathrm{ML})$ and muscle weight $=105.592+0.631 \times(\mathrm{CSA})$.

Table 2. Growth and carcass characteristics and relative weight of muscles, non-carcass parts, and some organs of male kids born to Turkish native goat kids.

\begin{tabular}{|c|c|c|c|c|c|}
\hline & $\begin{array}{c}\text { Angora } \\
(n=6)\end{array}$ & $\begin{array}{c}\text { Hair } \\
(n=6)\end{array}$ & $\begin{array}{c}\text { Honamli } \\
(n=6)\end{array}$ & $\begin{array}{l}\text { Kilis } \\
(n=6)\end{array}$ & $p$ \\
\hline \multicolumn{6}{|c|}{ Growth characteristics (kg) } \\
\hline Birth weight & $2.95 \pm 0.11^{b}$ & $2.90 \pm 0.29^{b}$ & $3.55 \pm 0.30^{\mathrm{a}}$ & $2.66 \pm 0.16^{\mathrm{b}}$ & 0.021 \\
\hline DWG & $0.12 \pm 0.06^{b}$ & $0.15 \pm 0.09^{b}$ & $0.17 \pm 0.09^{\mathrm{a}}$ & $0.13 \pm 0.03^{b}$ & 0.001 \\
\hline \multicolumn{6}{|c|}{ Carcass characteristics } \\
\hline $\mathrm{HCW}(\mathrm{kg})$ & $5.49 \pm 0.29^{c}$ & $7.01 \pm 0.37^{b}$ & $8.69 \pm 0.44^{\mathrm{a}}$ & $6.09 \pm 0.13^{b, c}$ & 0.001 \\
\hline CCW (kg) & $5.28 \pm 0.29^{c}$ & $6.79 \pm 0.38^{b}$ & $8.38 \pm 0.40^{\mathrm{a}}$ & $5.95 \pm 0.12^{b, c}$ & 0.001 \\
\hline $\operatorname{HCY}(\%)$ & $40.73 \pm 1.23^{b}$ & $43.38 \pm 1.78^{b}$ & $47.52 \pm 2.37^{\mathrm{a}}$ & $42.85 \pm 1.98^{b}$ & 0.004 \\
\hline $\operatorname{CCY}(\%)$ & $40.17 \pm 1.20^{b}$ & $41.97 \pm 1.69^{b}$ & $45.91 \pm 2.59^{\mathrm{a}}$ & $41.92 \pm 1.87^{\mathrm{b}}$ & 0.007 \\
\hline CL $(\%)$ & $0.56 \pm 0.13^{b}$ & $1.40 \pm 0.23^{\mathrm{a}}$ & $1.60 \pm 0.24^{\mathrm{a}}$ & $0.92 \pm 0.05^{\mathrm{b}}$ & 0.015 \\
\hline \multicolumn{6}{|c|}{ Muscle weights (g/100 g BW) } \\
\hline LD & $1.61 \pm 0.06^{\mathrm{a}, \mathrm{b}}$ & $1.54 \pm 0.26^{\mathrm{b}}$ & $1.76 \pm 0.07^{\mathrm{a}}$ & $1.57 \pm 0.10^{\mathrm{b}}$ & 0.049 \\
\hline ST & $1.40 \pm 0.06^{\mathrm{b}}$ & $1.35 \pm 0.25^{\mathrm{b}}$ & $1.74 \pm 0.08^{\mathrm{a}}$ & $1.18 \pm 0.11^{\mathrm{b}}$ & 0.047 \\
\hline \multicolumn{6}{|c|}{ Non-carcass parts (g/100 g BW) } \\
\hline Internal fat & $0.86 \pm 0.07^{\mathrm{a}}$ & $0.43 \pm 0.06^{b}$ & $0.65 \pm 0.15^{\mathrm{a}, \mathrm{b}}$ & $0.83 \pm 0.05^{\mathrm{a}}$ & 0.009 \\
\hline Kidney fat & $0.25 \pm 0.02$ & $0.24 \pm 0.03$ & $0.25 \pm 0.07$ & $0.26 \pm 0.02$ & 0.776 \\
\hline Total fat & $1.11 \pm 0.07^{\mathrm{a}}$ & $0.66 \pm 0.07^{\mathrm{b}}$ & $0.90 \pm 0.22^{\mathrm{a}}$ & $1.08 \pm 0.06^{\mathrm{a}}$ & 0.048 \\
\hline Head & $6.87 \pm 0.04$ & $7.29 \pm 0.51$ & $8.00 \pm 0.70$ & $7.33 \pm 0.28$ & 0.389 \\
\hline Pelt & $13.14 \pm 0.43^{\mathrm{a}}$ & $9.08 \pm 0.65^{b}$ & $9.38 \pm 1.05^{b}$ & $7.82 \pm 0.16^{\mathrm{b}}$ & 0.001 \\
\hline Feet & $2.89 \pm 0.03^{b}$ & $3.83 \pm 0.42^{\mathrm{a}}$ & $4.46 \pm 0.43^{\mathrm{a}}$ & $3.78 \pm 0.11^{\mathrm{a}}$ & 0.014 \\
\hline Small intestine & $2.89 \pm 0.03^{b}$ & $3.83 \pm 0.42^{\mathrm{a}}$ & $4.46 \pm 0.43^{\mathrm{a}}$ & $3.78 \pm 0.11^{\mathrm{a}}$ & 0.003 \\
\hline Reticulo rumen & $3.14 \pm 0.11^{\mathrm{a}}$ & $3.88 \pm 0.34^{\mathrm{a}}$ & $2.45 \pm 0.30^{\mathrm{b}}$ & $3.20 \pm 0.06^{\mathrm{a}}$ & 0.004 \\
\hline \multicolumn{6}{|c|}{ Organ weight (g/100 g BW) } \\
\hline Lung & $1.71 \pm 0.08$ & $1.82 \pm 0.17$ & $2.34 \pm 0.29$ & $1.83 \pm 0.06$ & 0.082 \\
\hline Liver & $2.21 \pm 0.05$ & $2.35 \pm 0.18$ & $2.42 \pm 0.14$ & $2.06 \pm 0.07$ & 0.214 \\
\hline Kidney & $0.52 \pm 0.02$ & $0.52 \pm 0.04$ & $0.48 \pm 0.07$ & $0.51 \pm 0.02$ & 0.801 \\
\hline Heart & $0.66 \pm 0.02^{\mathrm{a}}$ & $0.64 \pm 0.04^{\mathrm{a}}$ & $0.63 \pm 0.07^{\mathrm{a}}$ & $0.45 \pm 0.01^{\mathrm{b}}$ & 0.010 \\
\hline Spleen & $0.39 \pm 0.04^{\mathrm{a}}$ & $0.35 \pm 0.03^{\mathrm{a}}$ & $0.31 \pm 0.05^{\mathrm{a}, \mathrm{b}}$ & $0.21 \pm 0.01^{\mathrm{b}}$ & 0.011 \\
\hline Testis & $0.23 \pm 0.02$ & $0.26 \pm 0.09$ & $0.20 \pm 0.03$ & $0.21 \pm 0.01$ & 0.177 \\
\hline
\end{tabular}

$\mathrm{a}, \mathrm{b}, \mathrm{c}$ means in rows with different superscripts are significantly different at $p<0.05$. DWG $=$ daily weight gain from birth to weaning, $\mathrm{HCW}=$ hot carcass weight, $\mathrm{CCW}=$ cold carcass weight, $\mathrm{HCY}=$ hot carcass yield, $\mathrm{CCY}=$ cold carcass yield, $\mathrm{CL}=$ chilling loss, $\mathrm{BW}=$ body weight, $\mathrm{LD}=$ longissimus-dorsi muscle, $\mathrm{ST}=$ semitendinosus muscle.

Table 3. Pearson correlation coefficients between carcass characteristics and muscle metric measurements for the pooled data of Turkish indigenous goat breeds.

\begin{tabular}{cccccccc}
\hline Variable & HCW & CCW & HCY & CCY & CL & LDW & STW \\
\hline LD & & & & & & & \\
MD & 0.281 & 0.301 & 0.395 & 0.412 & -0.216 & $0.698^{* *}$ & - \\
ML & 0.074 & 0.084 & 0.384 & 0.376 & -0.001 & $0.723^{* *}$ & - \\
CSA & 0.210 & 0.226 & 0.414 & 0.415 & -0.095 & $0.793^{* *}$ & - \\
LDW & 0.343 & 0.367 & 0.373 & 0.390 & -0.250 & - & - \\
ST & & & & & & & \\
MD & -0.028 & -0.039 & 0.063 & 0.023 & 0.336 & - & $0.528^{*}$ \\
ML & 0.033 & 0.032 & 0.090 & 0.074 & 0.120 & - & $0.751^{* *}$ \\
CSA & -0.036 & -0.034 & 0.082 & 0.070 & 0.088 & - & $0.699^{* *}$ \\
STW & 0.265 & 0.279 & 0.385 & 0.388 & -0.096 & - & - \\
\hline
\end{tabular}

HCW $=$ hot carcass weight, $\mathrm{CCW}=$ cold carcass weight, $\mathrm{HCY}=$ hot carcass yield, $\mathrm{CCY}=$ cold carcass yield, $\mathrm{CL}$ $=$ chilling loss, $\mathrm{LDW}=$ longissimus-dorsi muscle weight, $\mathrm{STW}=$ semitendinosus muscle weight, $\mathrm{MD}=$ muscle depth, $\mathrm{ML}=$ muscle length CSA $=$ cross-sectional area. ${ }^{* *} p<0.01,{ }^{*} p<0.05$. 


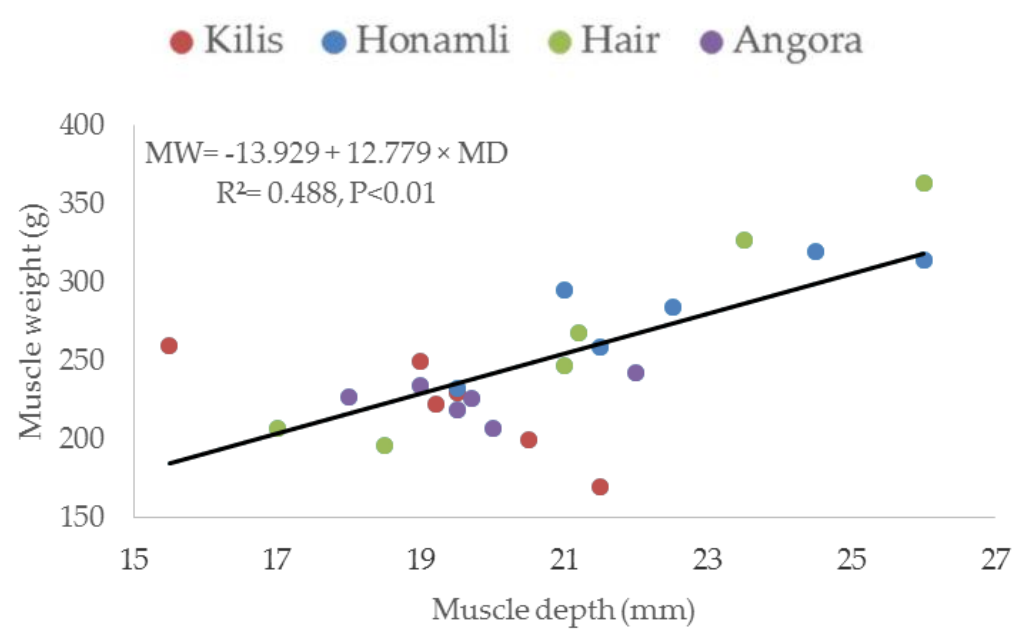

(a)

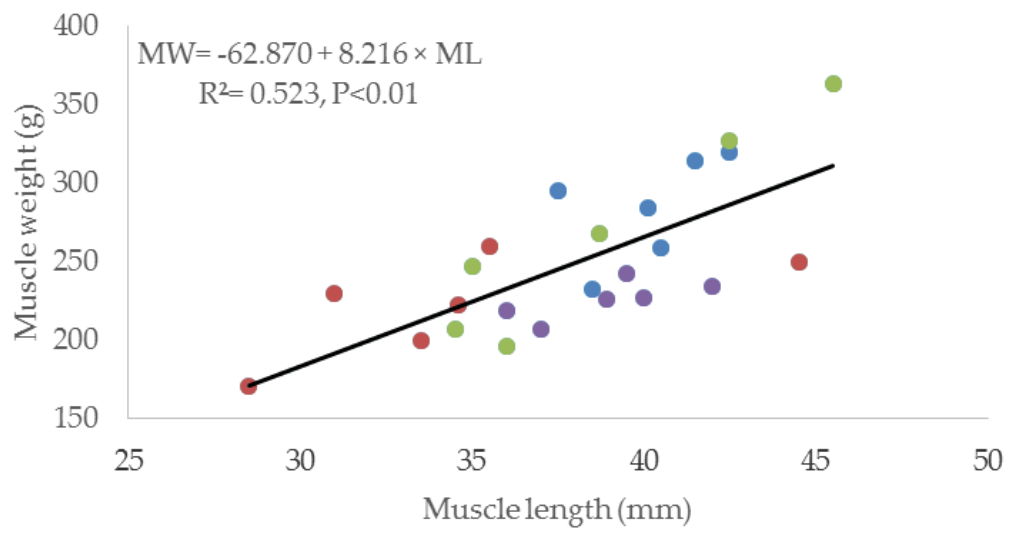

(b)

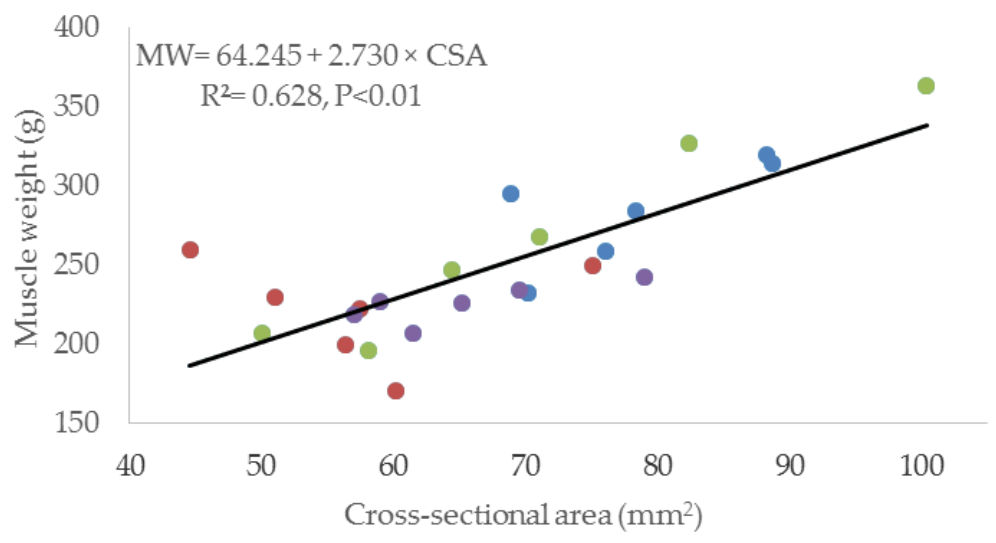

(c)

Figure 1. Regression graphs of metric measurements (a) muscle depth, (b) muscle length, (c) crosssectional area) on weight in longissimus-dorsi muscle for 24 kids born to Turkish native goat breeds. 


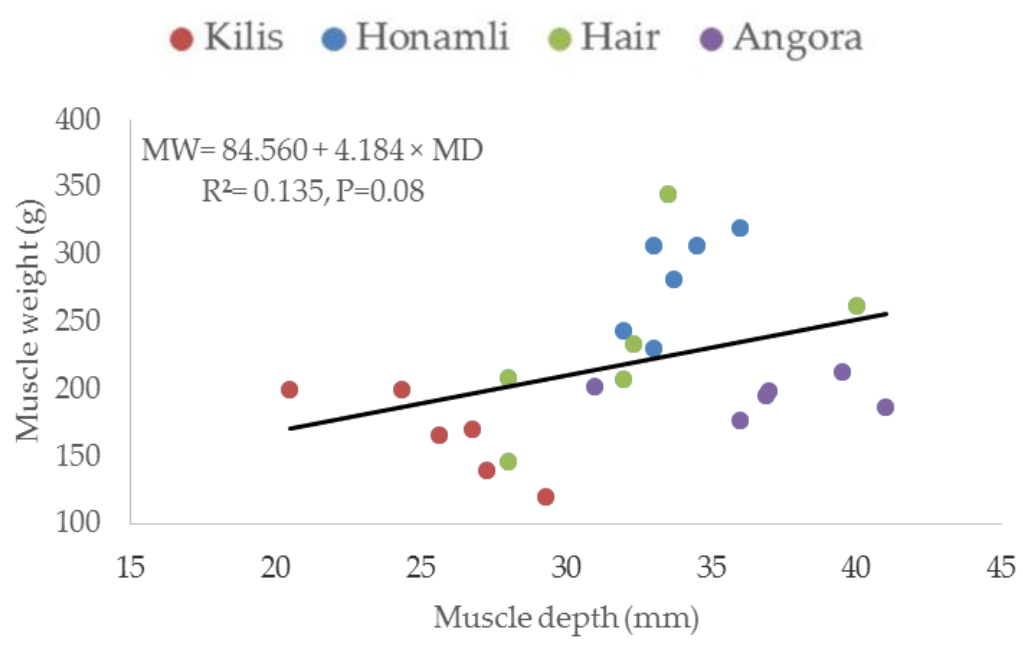

(a)

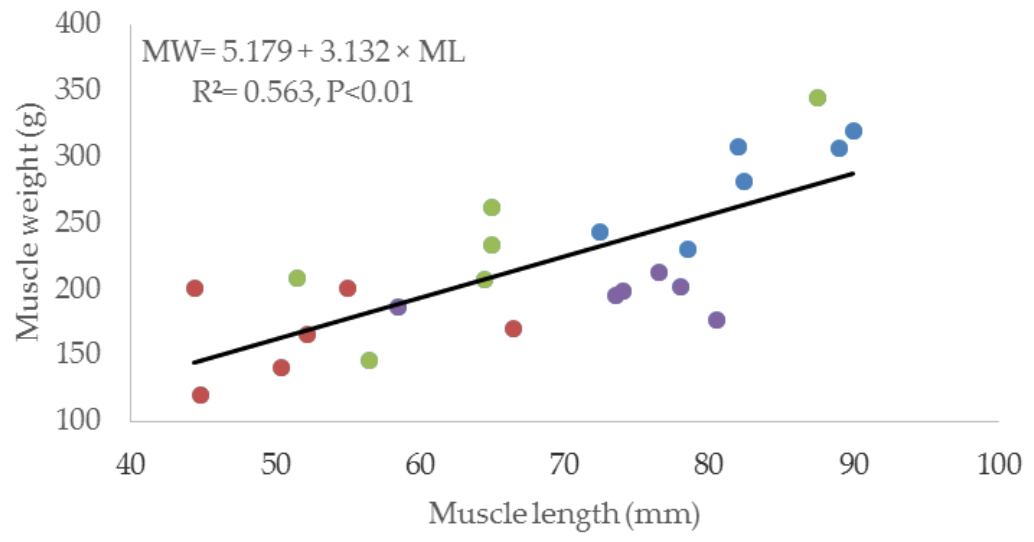

(b)

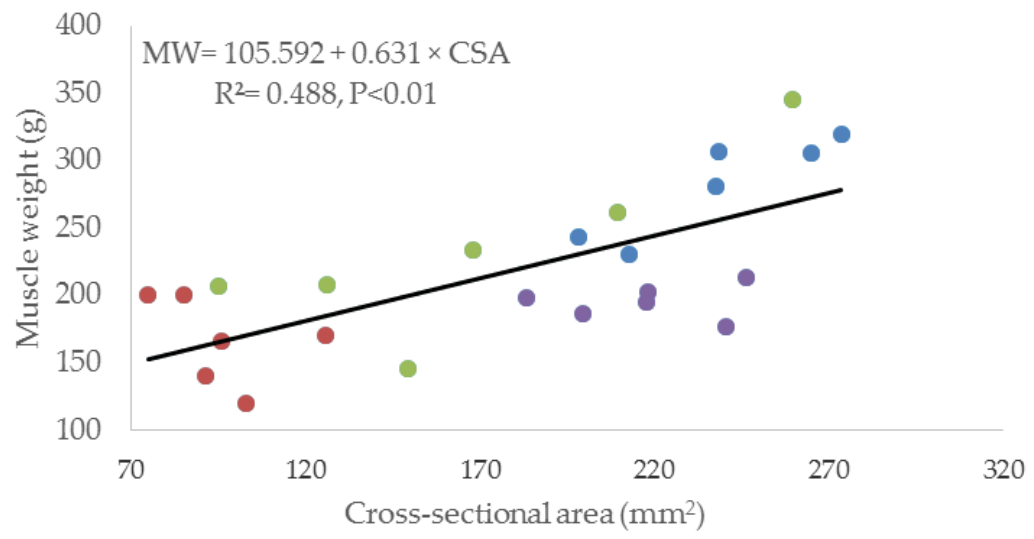

(c)

Figure 2. Regression graphs of metric measurements (a) muscle depth, (b) muscle length, (c) crosssectional area) on weight in semitendinosus muscle for 24 kids born to Turkish native goat breeds.

\section{Discussion}

Although birth weight is affected by many factors, each Turkish native breed has a characteristic birth weight [10,11]. Birth weight is one of the most critical factors affecting postnatal survival and growth [25-28]. Previous studies reported that offspring with 
low birth weight have a lower survival rate and growth rate until weaning [25-28]. In agreement with past studies [20-22], the results of the present study showed that Honaml kids had a higher birth weight and daily weight gain from birth to weaning than other breeds. Similarly, Akbaş and Saatçi [20], Keskin et al. [21], and Şenyüz [22] reported that Honamlı kids had higher birth weight than Hair, Honamlı $\times$ Hair crossbred, and Angora (except for Kilis), and the daily weight gain of Honamlı kids was higher than that of Angora, Hair, and Kilis breeds. Significant differences among breeds were observed for hot and cold carcass weights, in agreement with previous studies $[16,17,19,20]$. These differences could be attributed to a higher mature body weight and, therefore, higher growth rate and fatness. Honamlı kids, which have the highest adult body weight among Turkish indigenous goat breeds [10], had the highest carcass weight, which led to a higher slaughter weight for finished Honamlı kids following the fattening period. Previous studies reported that weaning weight influenced the post weaning growth performance, and heavy weaned animals reach slaughter weight in a shorter time [29,30]. Additionally, Ekiz et al. [13] and Sañudo et al. [15] also noticed differences among goat breeds considering the differences in mature body size.

Carcass yield is a crucial production criterion, and it expresses the ratio of live weight to carcass weight. Many factors influence carcass yield, such as alimentary tract size and fill, slaughtering procedures, body components (head, organs, intestine, pelt, and feet), body fat distribution, and secondary sex characteristics [31]. In addition, carcass yield must be interpreted carefully, and comparisons must be made between species and breeds [32]. The carcass yield of goats increases with age, body mass, and fatness and ranges from 40 to $56 \%$ [31]. Although there are differences in hot and cold carcass yield among breeds, the results of the present study are in agreement with results of previous studies for Angora [23], Hair [19,20], Honaml1 [19,20], and Kilis [18] kids. In the present study, the fact that the relative weights of some organs (heart and spleen), gastrointestinal tract components (empty small intestine and reticulo rumen), non-carcass parts (internal fat, pelt, and feet), and the carcass weight differed between breeds explains the reason for the difference in carcass yield. Previous studies indicated that differences in terms of carcass yield among breeds were associated with differences in the weights of non-carcass parts and organs [31-34]. Interestingly, although the non-carcass parts and organs of Honamlı kids were not lighter than those of other breeds, the carcass yield was higher than that of other breeds. The higher carcass yield of Honamlı kids may have been due to a more significant carcass weight [35]. An increase in carcass yield with increasing carcass weight has been noted in Honamlı breeds, in agreement with Peña et al. [12] and Marichal et al. [36].

Many studies have reported the relationships between carcass (such as weight, yield, and chilling loss) and fat (back fat thickness, total fat, and subcutaneous plus intermuscular fat contents) characteristics [20,37]. Okeudoa and Mossb [37] indicated that the fat content of carcass explained the percentage of the total variation in the chilling rate. The same authors showed that chilling loss was negatively correlated with back fat thickness and total fat [37]. Similarly, Akbaş and Saatc1 [20] suggested that the higher chilling losses might be associated with lower back fat thickness and compactness values. The present study determined that Honamlı and Hair kids had a higher chilling loss. Interestingly, compared to other breeds, the carcass of Hair kids had lower internal and total fat contents (Table 2). A higher chilling loss in the carcass of Hair kids was probably due to these carcasses' lower fatness, especially regarding the Angora and Kilis kids. In agreement with the results of previous studies $[20,37,38]$, the low carcass fat of Hair kids may have increased the chilling loss, although this phenomenon was not detected in Honamli kids.

Previous studies demonstrated that muscling in lambs is associated with post-weaning eye muscle depth, which is affected by the cellular responses, fiber number, and weight of different muscles [26,39]. The increase in the mass muscle weight during growth is the result of the increase in muscle fiber number and cross-sectional area and the increase in muscle length [40]. Moreover, the differentiation in muscle fibers hyperplasia of fetuses 
during gestation may affect postnatal muscle weight [28]. Although the weight of the LD and ST muscles did not correlate with carcass weight in all breeds, Honamlı kids had heavier LD (except for Angora) and ST muscle weights compared to the other breeds in the present study. These results suggest that hyperplasia of muscle fibers, which increases the number of muscle fibers during fetal growth and development, in the skeletal muscle mass of Honaml kids may be higher than in that of the other three breeds, and this may be responsible for increasing the muscle weights of Honaml kids. This interpretation is supported by the results of Şirin [41], who reported that the total muscle fiber numbers of Honamlı kids were higher than those of kids born to Angora and Kilis breeds.

The correlations of live weight and muscle dimensions, especially in LD muscle, are more valuable indicators for the genetic improvement of carcass yield and composition in livestock [42,43]. Muscle dimensions of LD muscle such as muscle width, depth, area, and the thickness of the fat covering on muscle mass are vital traits in the small ruminant industry for determining the carcass characteristics of live animals; therefore, most selection programs include these traits, and scientists and farmers try to improve these $[43,44]$. Although there was no a meaningful relationships between muscle (LD and ST) weights and carcass weight, strong relationships between metric measurements and weights of both LD and ST muscles from kids born to Angora, Hair, Honaml, and Kilis goat breeds were determined. The present study results indicated that metric measurements might estimate the weight of each muscle mass in the carcass. Moreover, metric dimensions may be used as a tool to reveal the meat potential in carcasses of kids from native breeds due to the high correlation with mass muscle weight.

\section{Conclusions}

In conclusion, our results confirm that Honamlı kids slaughtered at weaning are superior to other indigenous goat breeds of Turkey in this study with regards to growth performance, carcass, and muscle yield. This suggests that the Honamlı breed would be a good choice to use in a meat production system where goats are fattened beyond weaning age. Therefore, the potential as a meat goat breed of Honaml lies in birth weight and pre-wean growth. According to consumer demand, differences among breeds, especially carcass characteristics, may help produce alternative kid meat or meat products. To better understand the carcass and meat quality differences among goat breeds, more comparisons among indigenous breeds are needed as well as the evaluation of different criteria (age, weight, and rearing system) to obtain a broad and objective point of view.

Author Contributions: Conceptualization, U.Ş. and E.Ş.; methodology, U.Ş., E.Ş. and A.G.F.; validation, H.Ö., U.Ş. and D.P.; formal analysis, U.Ş. and H.Ö.; investigation, U.Ş. and E.Ş.; resources, U.Ş. and E.Ş.; data collection, U.Ş., E.Ş. and A.G.F.; data curation, U.Ş. and H.Ö.; writing-original draft preparation, U.Ş., H.Ö., E.Ş., A.G.F. and D.P.; writing—review and editing, H.Ö., U.Ş., E.Ş., A.G.F., M.K. and D.P.; visualization, U.Ş. and H.Ö.; supervision, U.Ş., E.Ş., D.P. and M.K.; project administration, U.Ş., E.Ş., D.P. and M.K.; funding acquisition, D.P. and M.K. All authors have read and agreed to the published version of the manuscript.

Funding: This article was supported by the Polish National Agency for Academic Exchange under Grant No. PPI/APM/2019/1/00003.

Institutional Review Board Statement: The authors confirm that the ethical policies of the journal, as noted on the journal's author guidelines page, have been adhered to. The experimental procedures were approved by the Local Animal Care and Ethics Committee of Kırşehir Ahi Evran University, Kırşehir, Turkey (approval number: 021013-4.1.9), ensuring compliance with EC Directive 86/609/EEC for animal experiments.

Informed Consent Statement: Not applicable.

Data Availability Statement: To obtain the data, please contact the authors U.S. and E.Ş. 
Acknowledgments: The authors acknowledge the financial support from the Republic of Turkey Ministry of Agriculture and Forestry General Directorate of Agricultural Research and Policies (Grant No. TAGEM/15/AR-GE/24) to carry out this study.

Conflicts of Interest: The authors declare no conflict of interest and none of the authors of this paper has a financial or personal relationship with other people or organizations that could inappropriately influence or bias the content of the paper.

\section{References}

1. Cloete, S. Breeding in developing countries and tropics. In Encyclopedia of Sustainability Science and Technology; Meyers, R.A., Ed.; Springer: New York, NY, USA, 2012.

2. Abd-Allah, S.; Mohamed, M.I.; Shoukry, M.M.; Salman, F.M.; Abd-El Rahman, H.H. Assessment of the traditional goat production systems in rural areas of the Nile Delta in Egypt. Bull. Natl. Res. Cent. 2019, 43, 114. [CrossRef]

3. Teufel, N.; Küttner, K.; Gall, C. Contribution of goat husbandry to household income in the Punjab (Pakistan): A review. Small Rumin. Res. 1998, 28, 101-107. [CrossRef]

4. Kumar, S.; Deoghare, P.R. Goat rearing and rural poor: A case study from India. In Proceedings of the 7th International Conference on Goats, Tours, France, 15-21 May 2000; pp. 554-556.

5. FAO. Faostat, Live Animals Data. Available online: http://www.fao.org/faostat/en/\#data/QA (accessed on 12 February 2020).

6. TurkStat. Turkish Statistical Institute, Livestock Statistics. Available online: http://www.turkstat.gov.tr (accessed on 12 February 2020).

7. Kaymakçı, M.; Dellal, G. Turkey and world goat breeding, goat farming. In Meta Basım Matbaacılık Hizmetleri; Kaymakçı, M., Ed.; İzmir İli Damızlık Koyun-Keçi Birliği Yayınları: İzmir, Turkey, 2006; pp. 3-15.

8. Şen, U.; Şirin, E.; Filik, G.; Soydan, E. The effect of breed on instrumental meat quality traits of weaning kids from Turkish indigenous goat breeds. Large Anim. Rev. 2020, 26, 19-24.

9. Zervas, G.; Tsiplakou, E. The effect of feeding systems on the characteristics of products from small ruminants. Small Rumin. Res. 2011, 101, 140-149. [CrossRef]

10. Yılmaz, O.; Kor, A.; Ertuğrul, M.; Wilson, R.T. The domestic livestock resources of Turkey: Goat breeds and types and their conservation status. Anim. Genet. Resour. 2012, 51, 105-116. [CrossRef]

11. Daskiran, I.; Koluman, N. Goat breeds of Turkey and their specific characteristics. In Proceedings of the European Regional Conference on Goats (ERCG 2014), Debrecen, Hungary, 8-11 April 2014.

12. Peña, F.; Bonvillani, A.; Freire, B.; Juárez, M.; Perea, J.; Gómez, G. Effects of genotype and slaughter weight on the meat quality of Criollo Cordobes and Anglonubian kids produced under extensive feeding conditions. Meat Sci. 2009, 83, 417-422. [CrossRef] [PubMed]

13. Ekiz, B.; Ozcan, B.; Yilmaz, A.; Tolu, C.; Savas, T. Carcass quality characteristics of Hair Goat and Saanen $\times$ Hair Goat crossbred kids from intensive production system. J. Anim. Feed Sci. 2010, 19, 368-378.

14. Boyazoglu, J.; Morand-Fehr, P. Mediterranean dairy sheep and goat products and their quality, a critical review. Small Rumin. Res. 2001, 40, 1-11. [CrossRef]

15. Sañudo, C.; Campo, M.M.; Muela, E.; Olleta, C.J.L.; Delfa, B.R.; Jiménez, B.R.; Alcalde, M.J.; Horcada, A.; Oliveira, I.; Cilla, I. Carcass characteristics and instrumental meat quality of suckling kids and lambs. Span. J. Agric. Res. 2012, 10, 690-700. [CrossRef]

16. Bayraktaroğlu, E.A.; Akman, N.; Tuncel, E. Effects of early on slaughter and carcass characteristics in crossbred Saanen $\times$ Kilis goats. Small Rumin. Res. 1988, 1, 189-194. [CrossRef]

17. Oman, J.S.; Waldron, D.F.; Griffin, D.B.; Savell, J.W. Carcass traits and retail display-life of chops from different goat breed types. J. Anim. Sci. 2000, 78, 1262-1266. [CrossRef]

18. Gürsoy, O.; Şentut, T.; Çankaya, S. Feedlot performance and carcass characteristics of Kilis goat breed. Maced. J. Anim. Sci. 2011, 1, 39-51.

19. Aktaş, A.H.; Gök, B.; Ateş, S.; Tekin, M.E.; Halıcı, İ.; Baş, H.; Erduran, H.; Kassam, S. Fattening performance and carcass characteristics of Turkish indigenous Hair and Honamlı goat male kids. Turk. J. Vet. Anim. Sci. 2015, 39, 643-653. [CrossRef]

20. Akbaş, A.S.; Saatçi, M. Growth, slaughter and carcass characteristics of Honaml, Hair and Honaml $\times$ Hair F1 male goat kids bred under extensive conditions. Turk. J. Vet. Anim. Sci. 2016, 40, 459-467. [CrossRef]

21. Keskin, M.; Gül, S.; Biçer, O.; Daşkıran, İ. Some reproductive, lactation and kid growth characteristics of Kilis goats under semiintensive conditions. Turk. J. Vet. Anim. Sci. 2017, 41, 248-254. [CrossRef]

22. Şenyüz, H.H. Fertility, live weight, survival rate, greasy fleece weight and quality traits of Angora goats in Turkey. Small Rumin. Res. 2021, 197, 106332. [CrossRef]

23. Erol, H.; Ünal, N. Meat production traits of Angora goat 1: Fattening, slaughter, and carcass characteristics of intact and castrated kids. Trop. Anim. Health Prod. 2021, 53, 142. [CrossRef] [PubMed]

24. Şen, U.; Şirin, E.; Ulutaş, Z.; Kuran, M. Fattening performance, slaughter, carcass and meat quality traits of Karayaka lambs. Trop. Anim. Health Prod. 2011, 43, 409-416. [CrossRef] [PubMed]

25. Greenwood, P.L.; Hunt, A.S.; Hermanson, J.W.; Bell, A.W. Effects of birth weight and postnatal nutrition on neonatal sheep: I. Body growth and composition, and some aspects of energetic efficiency. J. Anim. Sci. 1998, 76, 2354-2367. [CrossRef] 
26. Greenwood, P.L.; Hunt, A.S.; Hermanson, J.W.; Bell, A.W. Effects of birth weight and postnatal nutrition on neonatal sheep, II. Skeletal muscle growth and development. J. Anim. Sci. 2000, 78, 50-61. [CrossRef]

27. Dwyer, C.M.; Calvert, S.K.; Farish, M.; Donbavand, J.; Pickup, H.E. Breed, litter and parity effects on placental weight and placentome number, and consequences for the neonatal behavior of the lamb. Theriogenology 2005, 63, 1092-1110. [CrossRef]

28. Şen, U.; Şirin, E.; Aksoy, Y.; Ensoy, Ü.; Ulutaş, Z.; Kuran, M. The effect of maternal nutrition level during mid-gestation on post-natal muscle fiber composition and meat quality in lambs. Anim. Prod. Sci. 2016, 56, 834-843. [CrossRef]

29. Wolter, B.; Ellis, M. The effects of weaning weight and rate of growth immediately after weaning on subsequent pig growth performance and carcass characteristics. Can. J. Anim. Sci. 2001, 81, 363-369. [CrossRef]

30. Jones, A.G.; Takahashi, T.; Fleming, H.; Griffith, B.A.; Harris, P.; Lee, M.R.F. Using a lamb's early-life liveweight as a predictor of carcass quality. Animal 2021, 15, 100018. [CrossRef]

31. Casey, N.H.; Van Niekerk, W.A.; Webb, E.C. Goat meat. In Encyclopedia of Food Sciences and Nutrition; Caballero, B., Trugo, L., Finglass, P., Eds.; Academic Press: London, UK, 2003; pp. 2937-2944.

32. Dhanda, J.S.; Taylor, D.G.; Murray, P.J.; Pegg, R.B.; Shand, P.J. Goat meat production: Present status and future possibilities. Asian-Aust. J. Anim. Sci. 2003, 16, 1842-1852. [CrossRef]

33. Dhanda, J.S.; Taylor, D.G.; Mccosker, J.E.; Murray, P.J. The influence of goat genotype on the production of Capretto and Chevon carcass. 1. Growth and carcass characteristics. Meat Sci. 1999, 52, 355-361. [CrossRef]

34. Kadim, I.T.; Mahgoub, O.; Al-Ajmi, D.S.; Al-Mqbaly, R.S.; Al-Saqri, N.M.; Ritchie, A. An evaluation of the growth, carcass and meat quality characteristics of Omani goat breeds. Meat Sci. 2003, 66, 203-210. [CrossRef]

35. Berg, R.T.; Butterfield, R.M. New Concepts of Cattle Growth; Sydney University Press: Sydney, Australia, 1976; 240p.

36. Marichal, A.; Castro, N.; Capote, J.; Zamorano, M.J.; Argüello, A. Effects of live weight at slaughter (6, 10 and 25 kg) on kid carcass and meat quality. Livest. Prod. Sci. 2003, 83, 247-256. [CrossRef]

37. Okeudoa, N.J.; Mossb, B.W. Interrelationships amongst carcass and meat quality characteristics of sheep. Meat Sci. 2005, 69, 1-8. [CrossRef]

38. Nürnberg, K.; Wegner, J.; Ender, K. Factors influencing fat composition in muscle and adipose tissue of farm animals. Livest. Prod. Sci. 1998, 56, 145-156. [CrossRef]

39. Greenwood, P.L.; Gardner, G.E.; Hegarty, R.S. Indices of cellular development in muscles of lambs are influenced by sire estimated breeding values and pastoral nutritional system. Aust. J. Agric. Res. 2006, 57, 651-659. [CrossRef]

40. Wegner, J.; Albrecht, E.; Fiedler, I.; Teuscher, F.; Papstein, H.J.; Ender, K. Growth- and breed-related changes of muscle fiber characteristics in cattle. J. Anim. Sci. 2000, 78, 1485-1496. [CrossRef] [PubMed]

41. Şirin, E. Relationship between muscle fiber characteristics and meat quality parameters in Turkish native goat breeds. Indian J. Anim. Res. 2018, 52, 1526-1530.

42. Ulutaş, Z.; Aksoy, Y.; Şirin, E.; Saatci, M. Introducing the Karayaka sheep breed with its traits and influencing factors. Pak. J. Biol. Sci. 2008, 11, 1051-1054. [CrossRef] [PubMed]

43. Ulutaş, Z.; Aksoy, Y.; Şahin, A.; Şirin, E.; Şen, U.; Kuran, M. Genetic trends of body weight and some scanning traits of Karayaka lambs. Indian J. Anim. Res. 2018, 52, 1119-1123. [CrossRef]

44. Aksoy, Y.; Ulutaş, Z.; Şen, U.; Şirin, E.; Şahin, A. Estimates of genetic parameters for different body weights and muscle and fat depths of Karayaka lambs. Turk. J. Vet. Anim. Sci. 2016, 40, 13-20. [CrossRef] 